01242 AĹANINE DECREASEs THE PROTEIN REQUIREMENT OF INFANTS WITH INBORN ERRORS OF AMINO ACID METABOLISM. J. Wolff, S. Algert, D. Kelts, W.L. Nyhan. Dept. of Pediatrics, Univ. of Calif., San Diego. The hypothesis was tested that alanine might have an unique protein sparing effect by decreasing the catabolism in muscle of essential amino acids in order to supply the alanine-glucose cycle. Three infants with propionic acidemia, one with isovaleric acidemia, and one with OTC deficiency, were studied. First, the requirements of protein and calories for optimal growth were determined. Alanine was added isocalorically to diets containing less protein. Weight gain increased significantly $(p<0.001)$ by an average of $15 \mathrm{~g} /$ day when $0.05-0.25 \mathrm{~g} / \mathrm{Kg}$ of alanine were added to control diets of $70-130 \mathrm{Kcals} / \mathrm{Kg}$ and 0.55 to 1.0 protein/Kg. Nitrogen balance also increased significantly $(p<0.001)$ by $15 \mathrm{mg} / \mathrm{Kg}$. These increases in weight gain and nitrogen balance correlated with the amount of alanine added. Alanine supplementation enabled optimal growth (23-39 $\mathrm{g} /$ day) at lower levels of total nitrogen intake than did diets higher in whole protein. Other experiments showed that alanine also decreased the caloric requirement for growth. These effects were not see with other nonessential gluconeogenic amino acids such as glycine or glutamate. Alanine supplementation should be useful in other patients with disorders of amino acid metabolism. It may have utility in other catabolic states in which patients are candidates for hyperalimentation.

A NOVEL DIABETES SYNDROME IN AMERICAN BLACKS (TYPE

1243 1.5 DIABETES): INSULIN SECRETORY AND BINDING

STUDIES. W. E. Winter, N. K. Maclaren, W. J. Riley, M. S. Kappy, J. Jensen, and R. Spillar. Depts. Pathology and Pediatrics, University of Florida, Gainesville, Florida.

We have recently described an early onset $(<30 y / 0)$ diabetes syndrome ( 1.5 diabetes) in Blacks characterized by 1) Absence of HLA DR3 and DR4 (unusual in whites (3\%) vs Blacks with diabetes $(26 \%)$ ) and islet cell autoantibodies, 2) insulin dependence at onset, 3) frequent noninsulin dependent course thereafter and 4) frequent autosomal dominant family history of diabetes. We studied 14 such pts $(1.5 \mathrm{DM})$ for their plasma Cpeptide (CP) responses to oral sustacal (4 cal $/ \mathrm{kg}$ ) and their monocyte insulin binding characteristics. Six controls (C) and 5 pts with classical IDD were also studied for CP responses. Peak stimulated $C P$ levels for the $1.5 \mathrm{DM}$ pts $(0.31+0.8 \mathrm{pmol} / \mathrm{ml})$ were less than $C(0.78+0.05 ; p=0.004)$, but greater than IDD $(0.05+0.02)$ despite their having diabetes of greater duration $(4+3$ years for IDD vs $11+10$ years for 1.5 DM). Maximal insulin biñding in the $1.5 \mathrm{DM}$ pts was no different from 18 controls $(8.9+3.1 \%$ vs $7.4+1.6 \% ; p=0.10)$, and all 1.5 DM pts had normal insulin affinities. Insulin receptor sites were increased in pts with $1.5^{\circ} \mathrm{DM}(29.7 \mathrm{~K}+24$ sites/peripheral monocyte) over $\mathrm{C}$ $(13.2 \mathrm{~K}+5 \mathrm{~K} ; \mathrm{p}<0.01) .1 .5 \mathrm{DM}$ is reminiscent of Jamacian $(\mathrm{J})$ type diabetes. In summary, $1.5 \mathrm{DM}$ patients had CP responses intermediate between IDD and C. In general, there were no defects in insulin binding or affinity; however there appears to be upregulation of the number of insulin receptors secondary to insulinopenia.

EFFECTS OF GRADED HYPOXIA ON CEREBRAL

01244 PHOSPHATE POTENTIAL IN NEWBORN LAMBS: A CRITICAL BIOENERGETIC LEVEL. Donald P. Younkin,*

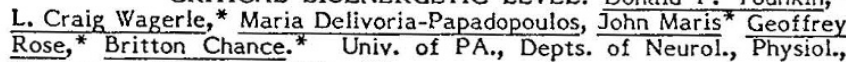
Biochem. and Biophys., Phila. PA.

These experiments were designed to measure the effects of graded hypoxia on cerebral phosphorus containing compounds (ATP; phosphocreatine, $\mathrm{PCr}$; inorganic phosphate, $\mathrm{Pi}$ ) and cerebral $\mathrm{pH}$ in newborn lambs. The phosphate potential $(\mathrm{PCr} / \mathrm{Pi})$ has emerged as a measure of bioenergetic reserve. In tissues of mature animals, resting $\mathrm{PCr} / \mathrm{Pi}$ is $>7$ and levels $<1.0$ are associated with lactic acidosis and cellular injury. We measured cerebral $\mathrm{pH}$ and phosphate potential with surface coil 31-PNMR spectroscopy in paralyzed, ventilated newborn lambs $(<7 \mathrm{D}) . \quad \mathrm{PCr}$ and $\mathrm{Pi}$ were measured from spectral heights; $\mathrm{pH}$ was calculated from the spectral shift of $\mathrm{Pi}$ relative to $\mathrm{PCr}$. In control lambs $\left(\mathrm{PaO}_{2}>75 \mathrm{mmHg}\right)$, cerebral $\mathrm{PCr} / \mathrm{Pi}$ was $\sim 1.7, \mathrm{pH} \sim 7.1$. Moderate hypoxia $\left(\mathrm{PaO}_{2} 35-43\right.$ $\mathrm{mmHg}$ ) did not alter the cerebral phosphate potential or $\mathrm{pH}$. Severe hypoxia $\left(\mathrm{PaO}_{2} \quad 13-20 \mathrm{mmHg}\right)$ caused a rapid decline in $\mathrm{PCr} / \mathrm{Pi}$ which stabilized after 5 min at $21.0 ; \mathrm{pH}$ did not fall as fast, but did not changes. Extreme hypoxia $\left(\mathrm{PaO}_{2}<12 \mathrm{mmHg}\right)$ caused a precipitous drop in $\mathrm{PCr} / \mathrm{Pi}$ to $\sim 0.7$ and the recovery time increased to $4.5 \mathrm{~min}$. When $\mathrm{PCr} / \mathrm{Pi}$ fell below 0.7 , MABP began to fall; if hypoxia was reversed, the recovery time increased to $12.5 \mathrm{~min}$; if hypoxia was not reversed, the lamb promptly expired. These studies demonstrate that newborn lambs develop lactic acidosis at a $\mathrm{PCr} / \mathrm{Pi} \sim 1.0$ and have a "critical" $\mathrm{PCr} / \mathrm{Pi}$ of $\sim 0.7$ at which the recovery time is prolonged as much as 5 -fold and beyond which the lamb dies, probably from cardiogenic shock.

\section{MORPHOGENESIS AND MALFORMATIONS}

NEW DYSMORPHIC SYNDROME WITH CNS, RENAL, AND

1245 SKELETAL ABNORMALITIES. Holly H. Ardinger, $\frac{\text { Stephen }}{1 \text {. }}$ The University of Iowa College of Medicine, Depts. of Pediatrics and Pathology, Iowa City.

We report a patient with a syndrome of distinctive facial, ocular, CNS, skeletal, and renal abnormalities. His past history was remarkable for congenital cataracts, marked developmental delay, and moderately severe scollosis. A convulsive disorder was recognized at 18 years of age. Numerous fractures with poor healing began occurring at age 23 . He subsequently developed evidence of progressive kidney disease leading to death from renal fallure at age 32 . Dysmorphic features when seen shortly before his demise included a fleshy face, a bulbous, upturned nose, large tongue, short neck, severe scoliosis, short limbs with small hands and feet, short, broad digits, and clinodactyly. Renal pathology revealed a tubulointerstitial nephritis simflar to that seen in Jeune's asphyxiating thoracic dysplasia, Alstrom's syndrome or nail-patella syndrome, as well as a prominent mesangial proliferative glomerulonephritis but clinical features were not consistent with any of these disorders. Other autopsy abnormalities included neuromigrational brain defects and diffuse markedly softened bones with multiple foci of apparent healing. An older brother was reported to have had the same phenotype, but died at age 13 years without an autopsy. An otherwise negative family history suggests either autosomal recessive or $X-1$ inked inheritance. We suggest that this may be a distinctive and previously unrecognized disorder.

1246 c. Birnholz. (Spon. by Car1 Hunt) Rush Medical Co11e ege, Dept. of Radiology, Rush-Presbyterian - St. Luke Medical Center, Chicago, I11.

Newer ultrasonic imaging systems with submillimeter resolution enable visualization facial details. The bony skeleton is observed from 11 weeks gestational age, the optic globes from 15 weeks, and the remaining soft tissues, progressively, after 18 weeks

Facial views provide a perceptually facilitated focus for expectant parents. Such views are sought routinely in each of our 2nd and 3rd trimester examinations. Technically, facial study can be used for mapping craniofacial developmental sequences and for detecting bony dysplasias, focal anomalies or distruptions (clefts) before the start of the 3rd trimester. Specific characteristics and anomalies detected antenatally have included cloping forehead, flat nasal angle, microphthalima, hypotelorism, epicanthal folds, malar and mandibular hypoplasias, cleft 1 ip, elongated philtrum, macroglossia, and various abnormalities of ear shape, size or location. Angular and spatial relations between skeletal parts can be quantitated and correllated with gestational age.

These methods have been applied in families at risk for craniofacial anomalies (i.e. Crouzon's disease) as a part of genetic counseling.

1247 PATIENTS, Xavier Cortada and Boris G. Kousseff,

Florida College of Medicine, Department of Pediatrics, Tampa.

We studied 225, non-selected, institutionalized individuals with mental retardation (MR). Profound MR was present in 176 $(78 \%)$, severe in $34(15 \%)$, moderate in 5 and mild MR in one; in $(78 \%)$, severe in $34(15 \%)$, moderate in 5 and mild MR in one; in
4 young children IQ scores were not available. Ninety patients (40\%) were non-ambulatory. Cerebral palsy was noted in 134 or $59 \%$ of the individuals (spastic in 116, choreoathetoid in 2 and mixed in 16), epilepsy in 120 (53\%), blindness in 41 (18\%) and deafness in 22 patients $(10 \%)$. There were 147 males and 78 females; 197 were 19 years old or younger. The patients were classified in 5 categories:

1. Recognizable conditions of known etiology, 128 patients, (19 patients with mendelian and 9 with polygenic / multifactorial inheritance, 21 with chromosome aberrations and 79 with environmental injuries).

2. Recognizable conditions of undetermined etiology, 15 patients.

3. Presumed etiology, 28 patients.

4. Unknown conditions with MCA/MR, 7 patients.

5. Unknown conditions with MR without MCA, 47 patients.

Only 18 patients (8\%) had Down syndrame; cambining categories 1 and 3 , postnatal brain injury was found in 32 patients (14\%) and perinatal brain injury in $51(23 \%)$. Recognizable conditions were found in 142 or $62.8 \%$ of the patients. 